\title{
One Base Deletion (c.2422delT) in the TPO Gene Causes Severe Congenital Hypothyroidism
}

\author{
Hakan Cangül1, Murat Doğan2, Yaman Sağlam3, Michaela Kendall4, Kristien Boelaert5, \\ Timothy G Barrett5, Eamonn R Maher6 \\ ${ }^{1}$ Bahçeşehir University Faculty of Medicine, Department of Medical Genetics, Istanbul, Turkey \\ 2 Yüzüncü YІl University, Faculty of Medicine, Division of Pediatric Endocrinology, Van, Turkey \\ 3 Medical Park Göztepe Hospital, Centre for Genetic Diagnosis, Istanbul, Turkey \\ 4 Southampton Faculty Department of Child Health, Division of Clinical and Experimental Sciences, UK \\ 5 University of Birmingham, School of Clinical and Experimental Medicine, Centre for Rare Diseases and \\ Personalised Medicine, Birmingham, UK \\ ${ }^{6}$ Cambridge University of Clinical Faculty, Academic Department of Medical Genetics, Cambridge, UK
}

\begin{abstract}
Objective: Congenital hypothyroidism $(\mathrm{CH})$ is the most common neonatal endocrine disorder and mutations in the TPO gene have been reported to cause $\mathrm{CH}$. Our aim in this study was to determine the genetic basis of $\mathrm{CH}$ in two affected individuals coming from a consanguineous family.

Methods: Since $\mathrm{CH}$ is usually inherited in autosomal recessive manner in consanguineous/multi-case families, we adopted a two-stage strategy of genetic linkage studies and targeted sequencing of the candidate genes. First we investigated the potential genetic linkage of the family to any known $\mathrm{CH}$ locus using microsatellite markers and then screened for mutations in linkedgene by Sanger sequencing

Results: The family showed potential linkage to the TPO gene and we detected a deletion (c.2422delT) in both cases. The mutation segregated with disease status in the family.

Conclusion: This study demonstrates that a single base deletion in the carboxyl-terminal coding region of the TPO gene could cause $\mathrm{CH}$ and helps to establish a genotype/phenotype correlation associated with the mutation. The study also highlights the importance of molecular genetic studies in the definitive diagnosis and accurate classification of $\mathrm{CH}$.
\end{abstract}

Key words: TPO gene, mutation, genetics, molecular, congenital hypothyroidism, thyroid dyshormonogenesis

Conflict of interest: None declared

Received: 25.04 .2014

\section{Introduction}

Congenital hypothyroidism $(\mathrm{CH})$ is the most common neonatal endocrine disorder with an incidence of $1 / 3500$ live births. It causes mental retardation and growth delay unless a timely and proper treatment is introduced (1). Molecular genetics analyses facilitate definitive diagnosis and accurate classification of $\mathrm{CH}$ and might also describe patient-specific targets for alternative treatment of the disease.

About $2 \%$ of $\mathrm{CH}$ is familial and to date, 11 causative genes have been described for the pathogenesis of inherited $\mathrm{CH}$ (2). Table 1 shows the details of all these loci and associated clinical phenotypes. Some of these genes are associated with primary thyroid dysgenesis $(3,4)$ and some with thyroid dyshormonogenesis (TDH) (5). Currently, there are seven genes known to cause congenital $\mathrm{TDH}$ which encode for proteins involved in thyroid hormone biosynthesis (6).

Major steps in thyroid hormone synthesis include oxidation and covalent linkage of iodide to tyrosine residues of thyroglobulin (TG) catalysed by thyroid peroxidase (TPO) enzyme (7). This latter reaction requires hydrogen peroxide $\left(\mathrm{H}_{2} \mathrm{O} 2\right)$ as the final electron acceptor $(8,9)$. Therefore, the generation of $\mathrm{H} 2 \mathrm{O} 2)$ is a critical step in the synthesis of thyroid hormones (10). A defect in the system that generates $\mathrm{H} 2 \mathrm{O} 2)$, resulting in $\mathrm{CH}$, has been reported previously $(11,12,13)$. Two dual oxidases (DUOX1 and 2) have recently been identified as the components of the thyroid H2O2)-generating system $(14,15)$. TPO is a thyroid-specific heme peroxidase localised in the apical membrane of thyrocytes

\footnotetext{
Hakan Cangül MD, Bahçeşehir University Faculty of Medicine, Department of Medical Genetics, Istanbul, Turkey Gsm: +90 5337449433 E-mail: h.cangul@bham.ac.uk

C Journal of Clinical Research in Pediatric Endocrinology, Published by Galenos Publishing.
}

Address for Correspondence 
Cangül $\mathrm{H}$ et al.

Thyroid Peroxidase Gene Deletion

\begin{tabular}{|l|l|l|l|}
\hline \multicolumn{4}{|l|}{ Table 1. Genes causing congenital hypothyroidism, associated phenotypes and microsatellite markers used for their linkage analysis } \\
\hline Gene & Ch Locus & Phenotype ${ }^{*}$ & Microsatellite Markers \\
\hline NIS & $19 p 13.2$ & TDH1 & D19S566, D19S593 D19S103, D19S898 \\
\hline TPO & $2 \mathrm{p} 25$ & TDH2A & D2S2980, D2S323 D2S1780, D2S2245 \\
\hline PDS & $7 q 31$ & TDH2B & D7S2459, D7S692 D7S2456, D7S799 \\
\hline TG & $8 q 24$ & TDH3 & D8S1740, D8S256 D8S1746, D8S558 \\
\hline DEHAL1 & $6 q 25.1$ & TDH4 & D6S1654, D6S440 D6S1687, D6S960 \\
\hline THOXA2 & $15 q 21.1$ & TDH5 & D15S100, D15S123 D15S132, D15S977 \\
\hline THOX2 & $15 q 21.1$ & TDH6 & D15S100, D15S123 D15S132, D15S978 \\
\hline TSHR & $14 q 31$ & CHNG1 & D14S1433, D14S606 D14S1008, D14S610 \\
\hline PAX8 & $2 q 12-q 14$ & D2S2269, D2S160, D2S410, D2S1893 \\
\hline TSHB & $1 p 13$ & CHNG2 & D1S2756, D1S2881, D1S2852, D1S189 \\
\hline NKX2-5 & $5 q 34$ & CHNG4 & D5S400, D5S2075, D5S211, ATA52D02 \\
\hline${ }^{* A s ~ d e s c r i b e d ~ i n ~ O M I M ~ d a t a b a s e ; ~ T D H: ~ t h y r o i d ~ d y s h o r m o n o g e n e s i, ~ C H N G: ~ g o n g e n i t a l ~ n o n-7 ~ g o i t r o u s ~ h y p o t h y r o i d i s m, ~ C h: ~ c h o r o m o s o m a l ~}$
\end{tabular}

and plays a central role in the thyroid hormone biosynthesis. Mutations in TPO causing permanent $\mathrm{CH}$ are mostly inherited in an autosomal recessive fashion and to date, more than 60 distinct mutations have been described in this gene $(8,9)$.

To investigate the genetic background of $\mathrm{CH}$, our group of investigators have developed a two-tier strategy combining genetic linkage studies and full sequencing of candidate genes in familial cases and to date have identified several mutations in different $\mathrm{CH}$ genes $(16,17,18,19,20,21,22,23,24,25,26,27,28)$. In the current study, we aimed to determine the genetic cause of $\mathrm{CH}$ in a consanguineous family with two affected siblings. Here, we report a homozygous one-nucleotide deletion (c.2422delT) in the TPO gene detected in both cases and its associated clinical phenotypes.

\section{Methods}

The genetics of $\mathrm{CH}$ reported in our previous studies $(18,19,20,21,22,23)$ were investigated in two new cases born to a consanguineous Turkish family. When the older sister was first diagnosed at the age of nine months, she had growth retardation. Her hormone levels before treatment were thyroid stimulating hormone (TSH): $720 \mu \mathrm{lU} / \mathrm{mL}$ (normal range: 0.3-5), total thyroxine (T4) $<0.9 \mu \mathrm{g} / \mathrm{dL}$ (normal range: 6.6-17.2), free $\mathrm{T4}$ (fT4) $<0.09 \mathrm{ng} / \mathrm{dL}$ (normal range: 0.9-2.3), total triiodothyronine (T3) $<0.17 \mathrm{ng} / \mathrm{mL}$ (normal range: 1.05-3.45) and free T3 (fT3) $<0.2 \mathrm{pg} / \mathrm{mL}$ (normal range: $2-5$ ). This patient is currently 12 years old and has severe mental retardation. Her younger sister was diagnosed much earlier, on the eighth day of birth and had thyroid enlargement detected by thyroid scintigraphy. Hormone levels in this second patient were TSH: $860 \mu \mathrm{lU} / \mathrm{mL}$ (normal range: 0.3-5), total $\mathrm{T} 4<0.7 \mu \mathrm{g} / \mathrm{dL}$ (normal range: $6.6-17.2$ ), fT4 $<0.12$ ng/dL (normal range: $0.9-2.3$ ), total T3 $<0.15 \mathrm{ng} / \mathrm{mL}$ (normal range: $1.05-3.45$ ) and $\mathrm{fT} 3<0.2 \mathrm{pg} / \mathrm{mL}$ (normal range: $2-5$ ). This patient is now eight years old and her development is normal. Hypothyroid phenotype is permanent in both cases and they require continuous T4 treatment. The parents and a healthy sister are all free of any signs or symptoms of hypothyroidism. Informed consent was obtained from the family and venous blood samples were collected from all family members. All procedures performed were in accordance with the Declaration of Helsinki and the study was approved by relevant IRBs/Ethics Committees. DNA was extracted by using standard methods and stored at $-20^{\circ} \mathrm{C}$ until analysed.

\section{Potential Linkage Analysis}

First we performed linkage analysis to all 11 known $\mathrm{CH}$ loci in all family members with microsatellite markers (Table 1). Fluorescent labelling of one oligonucleotide of each primer pair enabled the sizing of PCR products in a capillary electrophoresis machine by the use of GeneMapper v4.0 software suite (Applied Biosystems, Warrington, UK). By combining genotypes for each microsatellite marker, we constructed haplotype tables for each family member. As autosomal recessive inheritance was assumed in consanguineous families, homozygosity of a particular haplotype for a locus in cases accompanied by heterozygosity of the same haplotype in both parents was taken as suggestive of linkage to that locus.

\section{Direct Sequence Analysis of the TPO Gene}

The TPO gene was sequenced by conventional Sanger sequencing and the primer sequences and PCR conditions are available upon request. PCR products were size-checked on $1 \%$ horizontal agarose gels and cleaned up using MicroCLEAN (Microzone, Haywards Heath, UK) or gel-extracted using QIAquickTM Gel Extraction kit (Qiagen, Crawley, UK). The purified PCR products were sequenced in both forward and reverse directions using the $A B I$ BigDye Terminator v3.1 Cycle Sequencing kits on an ABI Prism 3730 DNA Analyzer (Applied Biosystems, Warrington, UK). Analysed sequences were then 
downloaded using Chromas software and assessed for the presence of alterations.

\section{Results}

Haplotype tables were constructed for each family member by combining the scores for each marker to observe the segregation of the genotype along with the disease status. The linkage analysis using these tables indicated a potential linkage to the TPO locus in the family, i.e. both $\mathrm{CH}$ cases were homozygous for a disease-associated haplotype, while both parents and the healthy sister were all heterozygous for the same haplotype (Figure 1). Assuming an autosomal recessive inheritance model which is the most likely pattern in consanguineous families, these results suggested that the disease-associated haplotype segregated with the disease status in the family. Therefore, we proceeded to sequence the coding region (and flanking

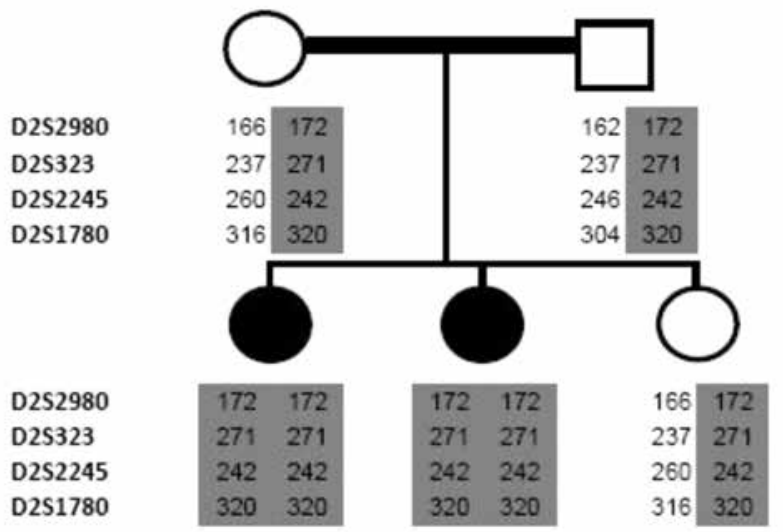

Figure 1. The scores of microsatellite marker analysis surrounding the TPO locus in family members. The markers used are listed on the left and the disease associated haplotype is shaded in grey

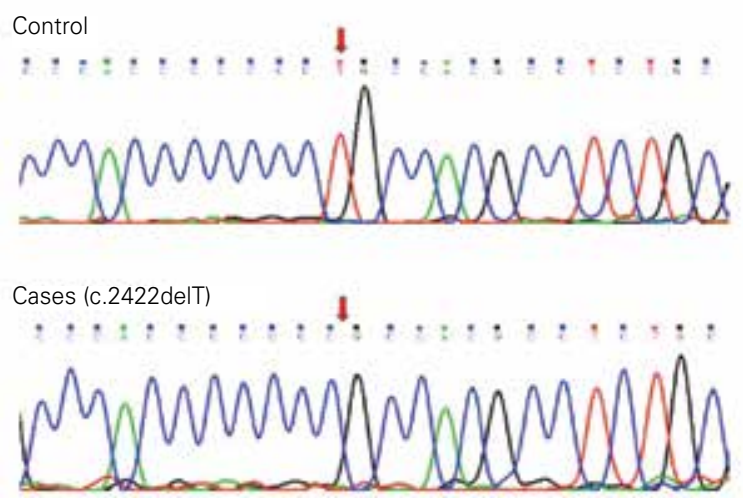

Figure 2. Sequence electropherograms of exon 14 in the TPO gene showing the homozygous deletion c. 2422delT in the cases (bottom panel) compared to the control (upper panel). Red arrows point to the site of the deletion sequences) of the TPO gene in all members of the family.

Direct sequencing analysis revealed a homozygous deletion of T nucleotide in codon 808 of the TPO gene (c.2422delT) in both affected siblings, which results in a frameshift mutation and leads to an early stop codon in exon 14 of the gene (p.Cys808AlafsX24). The parents and the unaffected sister all carried the mutation at heterozygous state which is consistent with the linkage results (Figure 2). Codon 808 is located in exon 14 of the 17-exon TPO gene and this mutation is expected to result in a truncated protein product which will lack carboxy-terminal catalytic domains. This in turn could render TPO protein completely non-functional.

\section{Discussion}

It is well known that $\mathrm{CH}$, if untreated, may lead to severe developmental delay and genetic defects have been long been implicated in the etiology of the disease. Currently, improving genetic analyses provide a powerful tool to unravel the pathogenesis of the disease and as the number of causative genes grows, the underlying molecular mechanisms become clearer in increasing number of patients. This is especially important for TDH as it is often inherited autosomal recessively where both parents usually are healthy carriers of a mutation in a particular causative gene.

To date, 11 causative genes have been described for $\mathrm{CH}$, seven (TPO, TG, NIS, PDS, IYD, DUOX2, DUOXA2) of which are associated with TDH phenotype and encode proteins involved in the biosynthesis of thyroid hormones (6). We developed a two-tier strategy, combining genetic linkage and sequencing techniques, to investigate the mutations in all causative $\mathrm{CH}$ genes, but our efforts were most fruitful with the TDH phenotype. This strategy is still cost-effective compared to full sequencing of all known genes as some of these genes are considerably large. We have recently also been engaged in developing a new testing strategy based on next generation sequencing (NGS) technology covering all causative $\mathrm{CH}$ genes in one set. As the prices of NGS are constantly decreasing, in the near future, it might be feasible just to sequence all known-genes in all $\mathrm{CH}$ patients.

In the present study, exploiting the same strategy, we delineated the genetic background of the disease in a consanguineous family and detected a homozygous TPO deletion (c.2422delT) in both affected siblings which segregated with the disease status in the family, i.e. both obligatory carrier parents and one unaffected sibling were all heterozygous for the same mutation. This mutation was first described by Bakker et al (29) as pathogenic and associated with total iodine organification defect. These authors have concluded that this mutation entirely abolishes the function of the TPO enzyme. The severe phenotype in their patients was also evidenced by very low plasma thyroid hormone concentrations (both of T3 and T4) and highly elevated TSH levels. Radioiodine uptake and perchlorate discharge test results for our cases were not available, but the very low thyroid 
hormone levels associated with very high levels of TSH in our patients are in line with their observations and confirm the severe phenotype caused by c.2422delT mutation. Therefore, it would be plausible to suggest that there is a firm genotype/phenotype relationship associated with this TPO mutation.

In conclusion, we state that in these two patients, the $\mathrm{CH}$ was caused by c.2422delT TPO mutation and that this mutation is associated with severe $\mathrm{CH}$. Our study contributes to the establishment of a firm genotype/phenotype relationship associated with this mutation. Molecular genetic studies as such would allow the description of exact etiology and pathogenic mechanism of the disease in particular patients.

\section{Acknowledgements}

We are grateful to the family members who agreed to participate in this study.

\section{References}

1. Medeiros-Neto G, Knobel M, DeGroot LJ. Genetic disorders of the thyroid hormone system. In: Baxter JD (ed). Genetics in endocrinology, Philadelphia, Lippincott Williams \& Wilkins, 2002:375-402.

2. Park SM, Chatterjee VK. Genetics of congenital hypothyroidism. J Med Genet 2005:42:379-389.

3. Castanet $\mathrm{M}$, Polak $\mathrm{M}$, Bonaïti-Pellié $\mathrm{C}$, Lyonnet $\mathrm{S}$, Czernichow P, Léger J; AFDPHE (Association Française pour le Dépistage et la Prévention des Handicaps de l'Enfant). Nineteen years of national screening for congenital hypothyroidism: familial cases with thyroid dysgenesis suggest the involvement of genetic factors. J Clin Endocrinol Metab 2001;86:2009-2014.

4. Kopp P. Genetic defects in the etiology of congenital hypothyroidism. Endocrinology 2002;143:2019-2024.

5. Caputo M, Rivolta CM, Esperante SA, Gruñeiro-Papendieck L, Chiesa A, Pellizas CG, González-Sarmiento R, Targovnik HM. Congenital hypothyroidism with goitre caused by new mutations in the thyroglobulin gene. Clin Endocrinol (Oxf) 2007;67:351357. Epub 2007 May 28

6. Grasberger H, Refetoff S. Genetic causes of congenital hypothyroidism due to dyshormonogenesis. Curr Opin Pediatr 2011;23:421-428.

7. Targovnik HM, Esperante SA, Rivolta CM. Genetics and phenomics of hypothyroidism and goiter due to thyroglobulin mutations. Mol Cell Endocrinol 2010;322:44-55. Epub 2010 Jan 20

8. Ris-Stalpers C, Bikker H. Genetics and phenomics of hypothyroidism and goiter due to TPO mutations. Mol Cell Endocrinol 2010;322:38-43. Epub 2010 Feb 12

9. Belforte FS, Miras MB, Olcese MC, Sobrero G, Testa G, Muñoz L, Gruñeiro-Papendieck L, Chiesa A, González-Sarmiento R, Targovnik HM, Rivolta CM. Congenital goitrous hypothyroidism: mutation analysis in the thyroid peroxidase gene. Clin Endocrinol (Oxf) 2012;76:568-576.

10. Corvilain B, van Sande J, Laurent E, Dumont JE. The H2O2generating system modulates protein iodination and the activity of the pentose phosphate pathway in dog. Endocrinology 1991;128:779-785.

11. Kusakabe T. Deficient cytochrome b5 reductase activity in nontoxic goiter with iodide organification defect. Metabolism 1975;24:1103-1113.
12. Niepomniszcze $H$, Targovnik HM, Gluzman BE, Curutchet $P$. Abnormal $\mathrm{H} 2 \mathrm{O} 2$ supply in the thyroid of a patient with goiter and iodine organification defect. J Clin Endocrinol Metab 1987;65:344-348.

13. Figueiredo MD, Cardoso LC, Ferreira AC, Campos DV, da Cruz Domingos M, Corbo R, Nasciutti LE, Vaisman M, Carvalho DP. Goiter and hypothyroidism in two siblings due to impaired Ca_2/ $\mathrm{NAD}(\mathrm{P}) \mathrm{H}$-dependent $\mathrm{H} 2 \mathrm{O} 2$-generating activity. J Clin Endocrinol Metab 2001;86:4843-4848.

14. Dupuy C, Ohayon R, Valent A, Noël-Hudson MS, Dème D, Virion A. Purification of a novel flavoprotein involved in the thyroid NADPH oxidase. J Biol Chem 1999;274:37265-37269.

15. De Deken X, Wang D, Many MC, Costagliola S, Libert F, Vassart G, Dumont JE, Miot F. Cloning of two human thyroid cDNAs encoding new members of the NADPH oxidase family. J Biol Chem 2000;275:23227-23233.

16. Cangul $H$, Aycan Z, Olivera-Nappa A, Saglam $H$, Schoenmakers NA, Boelaert K, Cetinkaya S, Tarim O, Bober E, Darendeliler F, Bas V, Demir K, Aydin BK, Kendall M, Cole T, Högler W, Chatterjee VK, Barrett TG, Maher ER. Thyroid dyshormonogenesis is mainly caused by TPO mutations in consanguineous community. Clin Endocrinol (Oxf) 2013;79:275-281. Epub 2013 May 6

17. Baş VN, Cangul H, Agladioglu SY, Kendall M, Cetinkaya S, Maher ER, Aycan Z. Mild and severe congenital primary hypothyroidism in two patients by thyrotropin receptor (TSHR) gene mutation. J Pediatr Endocrinol Metab 2012;25:1153-1156.

18. Cangul H, Aycan Z, Saglam H, Forman JR, Cetinkaya S, Tarim O, Bober E, Cesur Y, Kurtoglu S, Darendeliler F, Bas V, Eren E, Demir K, Kiraz A, Aydin BK, Karthikeyan A, Kendall M, Boelaert K, Shaw NJ, Kirk J, Högler W, Barrett TG, Maher ER. TSHR is the main causative-locus in autosomal recessively inherited thyroid dysgenesis. J Pediatr Endocrinol Metab 2012;25:419-426.

19. Cangul H, Morgan NV, Forman JR, Saglam H, Aycan Z, Yakut T, Gulten T, Tarim O, Bober E, Cesur Y, Kirby GA, Pasha S, Karkucak M,Eren E, Cetinkaya S, Bas V, Demir K, Yuca SA, Meyer E, Kendall M, Hogler W, Barrett TG, Maher ER. Novel TSHR mutations in consanguineous families with congenital nongoitrous hypothyroidism. Clin Endocrinol (Oxf) 2010;73:671-677.

20. Cangul H, Saglam H, Aycan Z, Yakut T, Gulten T, Morgan NV, Forman JR, Karkucak M, Eren E, Cetinkaya S, Bas V, Demir K, Yuca SA, Kirby GA, Pasha S, Kendall M, Hogler W, Barrett TG, Maher ER. Locus heterogeneity and mutations in thyrotropin receptor gene in autosomal recessively inherited congenital hypothyroidism. J Med Genet 2010;47(Suppl 1):59.

21. Cangul H, Boelaert K, Dogan M, Saglam Y, Kendall M, Barrett TG, Maher ER. Novel truncating thyroglobulin gene mutations associated with congenital hypothyroidism. Endocrine 2014;45:206-212. Epub 2013 Aug 15

22. Schoenmakers NA, Cangul $H$, Nicholas A, Schoenmakers $E$, Lyons G, Dattani M, Peters C, Langham S, Habeb A, Deeb A, Puthi V, Park S-M, Maher ER, Chatterjee VKK. A comprehensive next generation sequencing-based strategy for genetic diagnosis in congenital hypothyroidism. Endocrine Abstracts 2013 doi:10.1530/endoabs.33.OC2.9

23. Cangul H, Aycan Z, Kendall M, Bas VN, Saglam Y, Barrett TG, Maher ER. A truncating DUOX2 mutation (R434X) causes severe congenital hypothyroidism. J Pediatr Endocrinol Metab 2014;:27:323-327.

24. Baş VN, Aycan Z, Cangul H, Kendall M, Ağladıoğlu SY, Çetinkaya $\mathrm{S}$, Maher ER. A missense thyroid peroxidase gene mutation (G319R) in two cases with congenital hypothyroidism. J Pediatr Endocrinol Metab 2014;27:383-387. 
Cangül $\mathrm{H}$ et al.

Thyroid Peroxidase Gene Deletion

25. Cangul H, Morgan NV, Pasha S, et al (2009) Genetic heterogeneity in congenital ypothyroidism. J Med Genet (Suppl 1): S74-S74

26. Cangul $H$, Schoenmakers NA, Saglam $H$, Doganlar $D$, Saglam Y, Eren E, Kendall M, Tarim O, Barrett TG, Chatterjee $K$, Maher ER. A deletion including exon 2 of the TSHR gene is associated with thyroid dysgenesis and severe congenital hypothyroidism. J Pediatr Endocrinol Metab 2014;27:731735.

27. Cangul H, Saglam H, Saglam $Y$, Eren E, Dogan D, Kendall M, Tarim O, Maher ER, Barrett TG. An essential splice site mutation (c.317+1G>A) in the TSHR gene leads to severe thyroid dysgenesis. J Pediatr Endocrinol Metab 2014 May 23. [Epub ahead of print]

28. Cangul H, Bas VN, Saglam Y, Kendall M, Barrett TG, Maher $E R$, Aycan Z. A nonsense thyrotropin receptor gene mutation (R609X) is associated with congenital hypothyroidism and heart defects. J Pediatr Endocrinol Metab 2014 Jun 19. [Epub ahead of print]

29. Bakker $B$, Bikker $H$, Vulsma $T$, de Randamie JS, Wiedijk BM, De Vijlder JJ. Two decades of screening for congenital hypothyroidism in The Netherlands: TPO gene mutations in total iodide organification defects (an update). J Clin Endocrinol Metab 2000;85:3708-3712. 